JA II (2) (2018)
JURNAL AUDI
Kajian Teori dan Praktik di bidang Pendidikan Anak Usia Dini
http://ejurnal.unisri.ac.id/index.php/jpaud
UNISRI
suRAKARTA

\title{
MENINGKATKAN MOTORIK HALUS MELALUI KOLASE DARI AMPAS KELAPA PADA ANAK TK KELAS B USIA 5-6 TAHUN

\author{
Siti Bari'ah ${ }^{1}$, Lydia Ersta Kusumaningtyas ${ }^{2}$ \\ Universitas Slamet Riyadi
}

\begin{tabular}{l}
\hline Info Artikel \\
\hline Sejarah Artikel: \\
Diterima Agustus 2017 \\
Disetujui November \\
2017 \\
Dipublikasikan Desem- \\
ber 2017 \\
\hline Keywords: \\
Smooth Motoric, \\
Collage Coconut \\
Ampas. \\
\hline
\end{tabular}

\begin{abstract}
Abstrak
Tujuan yang dicapai dalam penelitian ini adalah untuk mengetahui ada tidaknya peningkatan motorik halus setiap perta didik lainnya yang mengikuti permainan sambil belajar yakni kegiatan kolase dari ampas kelapa pada peserta didik di kelas B1 TK MTA Munggur Mojogedang Karanganyar Tahun Pelajaran 2016/2017. Penelitian ini menggunakan model siklus sehingga mengacu pada langkah-langkah Penelitian Tindakan Kelas. Menurut Suharsimi Arikunto Penelitian Tindakan Kelas memiliki 4 tahap yaitu perencanaan, tindakan, pengamatan dan refleksi. Subjek dalam penelitian berjumlah 20 anak dan penelitian ini terdiri dari dua siklus, masingmasing siklus terdiri dari 2 kali pertemuan/ tindakan. Analisis data menggunakan analisis deskriptif kritis komparatif dengan membandingkn nilai dari sikus pertama dan siklus kedua. Teknik pengumpulan data dengan teknik observasi yaitu untuk mengetahui perkembangan peserta didik, selanjutnya wawancara untuk mendapatkan informasi sebagai penguat dari hasil observasi, serta menggunakan dokumentasi untuk memperoleh hasil karya peserta didik. Berdasarkan hasil penelitian menunjukkan bahwa melalui kegiatan kolase dari ampas kelapa dapat meningkatkan motorik halus anak, dapat dibuktikan dari kondisi awal mendapatkan persentase sebanyak 10\% dengan 2 peserta didik. Pada siklus I sebanyak 15\% dengan 3 peserta didik. Selanjutnya siklus II pertemuan pertama sudah mengalami peningkatan yang derastis $80 \%$ dengan jumlah 16 peserta didik pada siklus II pertemuan ke-2 sebanyak 85\% dengan jumlah 17 peserta didik. Melalui kegiatan kolase ampas kelapa dapat meningkatkan motorik halus, dapat menempel sesuai dengan pola dengan sabar, dan dapat mengkoordinasi mata dan dapat menggerakkan pergelangan tangan agar lentur bagi anak sebagai dorongan meningkatkan motorik halus.

\section{Abstract}

The purpose of this research is to know whether there is any fine motor improvement every other students who follow the game while learning that is collage activity from coconut waste in the students in class B1 TK MTA Munggur Mojogedang Karanganyar Lesson Year 2016/2017. This research uses a cycle model so that it refers to Classroom Action Research steps. According Suharsimi Arikunto Classroom Action Research has 4 stages of planning, action, observation and reflection. Subjects in the study amounted to 20 children and the study consisted of two cycles, each cycle consisting of 2 meetings / actions. The data analysis used a comparative critical descriptive analysis by comparing the values of the first cycles and the second cycle. Data collection techniques with observation techniques that is to determine the development of learners, subsequent interviews to obtain information as a reinforcement of the observation, and use the documentation to obtain the work of learners. Based on the results of the study showed that through the collage activity of coconut dregs can improve the fine motor of the child, can be proven from the initial condition get a percentage of $10 \%$ with 2 learners. In cycle I as much as $15 \%$ with 3 students. Furthermore, the first cycle of the first meeting has experienced a dramatic increase of $80 \%$ with a total of 16 students in the second cycle of the second meeting as much as $85 \%$ with the number of 17 students. Through the collage activity of coconut dregs can improve the fine motor, can adhere to the pattern with patience, and can coordinate the eyes and can move the wrist to be flexible for the child as a boost of fine motor boost.

Keywords: Smooth Motoric, Collage Coconut Ampas.Education.

(C) 2018 FKIP Universitas Slamet Riyadi 


\footnotetext{
$\triangle$ Alamat korespondensi: J1. Sumpah Pemuda

No.18 Kadipiro, Surakarta

E-mail: barabariah@gmail.com
}

ISSN 2528-3359 (Print)

ISSN2528-3367 (Online)

\section{PENDAHULUAN}

Anak usia dini adalah masa keemasan (golden age) masa yang sangat penting sebagai suatu masa yang menjadikan dasar dan memberi pengaruh besar terhadap kualitas perkembangan anak selanjutnya. Oleh karena itu perlu pemberian stimulasi yang cukup. Sehingga melalui pemberian stimulasi yang benar pendidikan akan membantu pertumbuhan dan perkembangan yang sesuai aspek perkembangan anak. Pendidikan sebagai salah satu cara yang dapat dilakukan untuk mengembangkan suatu potensi anak usia dini.

Di era globalisasi ini pendidikan begitu penting untuk anak usia dini sehingga sebagai pendidik di suatu pendidikan formal yaitu TK di sekolahan tersebut pendidik mengembangkan dangan berbagai aspek perkembangan sesuai dengan kurikulum. Untuk meningkatkan berbagi aspek perkembangan, pemerintah semakin gencar menggalakannya diadakanya Pendidikan Anak Usia Dini sampai dengan dipelosok tanah air. Di dalam kurikulum terdapat aspekaspek perkembangan di antaranya nilai agama moral, sosial emosional, kognitif, bahasa seni, motorik kasar dan halus. Pendidikan juga berfungsi untuk meningkatkan motorik halus peserta didik.

Menurut Mursid (2015:11) perkembangan "motorik adalah proses seorang anak belajar untuk terampil mengerakkan tubuh. Motorik halus yakni gerakan-gerakan yang merupakan koordinasi otot-otot yang menuntut adanya kemampuan mengontrol gerakan-gerakan halus". Kegiatan motorik halus seperti dapat membedakan kasar halus, meremas, mewarnai, menulis dan lain sebagainya. Maka sangat perlunya pendidik untuk mengembangkan dan meningkatkan motorik halus dengan menggunakan media dan sumber media permainan edukatif untuk anak TK dalam belajar dan pembelajaran.

Salah satu komponen atau unsur pembelajaran anak yang memegang peran penting adalah terselenggaranya kegiatan pembelajaran yang menarik dan bermakna dengan pembelajaran kolase ampas kelapa. Menurut Hajar Pamadhi dan Evan Sukadi (2010:5.4) Kolase merupakan suatu karya seni rupa dua dimensi yang menggunakan bahan dasar tersebut sehingga dapat seni rupa tersebut dapat di padukan dengan bahan dasar lainnya dan akhirnya dapat menyatu sehingga dapat menjadi karya yang utuh sehingga dapat mengekpresikan perasaan orang yang sedang membuatnya.

Untuk mengembangkannya sumber belajar yang menarik mungkin bagi perkembangan dan kegiatan belajar anak TK yakni dengan kolase dari ampas kelapa, dikarenakan yang dapat dipadukan dengan bahan dasar lainnya. Sehingga membantu mengembangkan semua potensi anak. Perkembangan dan manipulasi lingkungan sehingga perlu dipahami dan diterima oleh setiap pendidik yang terlibat dalam penyelenggaraan pendidikan anak usia dini. Pemahaman selanjutnya perlu di realisasikan dalam pendidikan untuk memperoleh individu dan masyarakat yang berkualitas.

Pada kenyataanya di sekolahan TK MTA Munggur terdapat beberapa anak masih belum meningkat atau berkembang motorik halusnya, terlihat cara mereka mengerjakan pembelajaran yang dikasihkan oleh pendidik mereka mengerjakan dengan mencoret-coret tugas yang dikasihkan oleh pendidiknya. Sehingga dalam Dalam meningkatkan aspek motorik halus pada anak TK kelas atau kelompok B belajar dalam situasi yang utuh dan berkaitan dengan kehidupan mereka sehari-hari. Oleh karena itu guru perlu menggunakan sumber belajar yang relevan sesuai dengan karakteristik dan kebutuhan tersebut. Sehingga perlulah kejelian pendidik dalam melakukan pemilihan model dan metode pembelajaran yang dapat digunakan secara fleksibel dan 
Siti Bari'ah. Meningkatkan Motorik Halus Melalui Kolase Dari Ampas Kelapa Pada Anak Tk Kelas B Usia 5-6 Tahun

serba guna melalui media yang akan diberikan.

Anak adalah individu yang unik dan memiliki kekhususan tersendiri. Bahwa anak merupakan individu yang dilahirkan dengan memiliki potensi. Sehingga guru dan orang tua yang mengembangkan dan meningkatkan potensi yang ada pada anak. Berdasarkan pengamatan peneliti, anak-anak yang belum meningkat perkembangan motorik halus perlu di tingkatkan. Dengan motorik halus anak memiliki kemampuan menggunakan alat untuk mengeksplorasi dan mengekspresikan diri dalam berbagai bentuk. Sehingga memerlukan sarana media sehingga anak dapat memanfaatkan bendabenda di sekitarnya untuk meningkatkan motorik halus anak secara optimal.

Berdasarkan uraian di atas kiranya tepat jika dilakukan penelitian dengan judul "Meningkatkan Motorik Halus Melalui Kolase dari Ampas Kelapa pada Anak TK Kelas B Usia 5-6 Tahun di TK MTA MUNGGUR Tahun Pelajaran 2016/2017”. Menurut Mulyasa (2012:16) "Anak Usia Dini adalah individu yang sedang mengalami suatu proses pertumbuhan dan perkembangan yang begitu pesat, bahkan dikatakan sebagai lompatan perkembangan anak". Sehingga Anak Usia Dini memiliki rentang usia yang sangat berhaga dibanding dengan usia-usia selanjutnya dikarenakan perkembangan kecerdasan begitu luar biasa. Sehingga perlu dikembangkan melalui Pendidikan Anak Usia Dini.

Tujuan pengembangan motorik halus anak usia dini menurut Sujiono Bambang (2008:2.12) adalah:

1) Agar anak mampu berlatih menggerakkan pergelangan tangan dengan kegiatan menggambar dan mewarnai.

2) Agar anak mampu belajar keterampilan koordinasi mata dan tangan dan menggerakkan pergelangan tangan agar lentur.

3) Agar anak dapat belajar untuk berimajinasi dan berkreasi.

pengembangan motorik halus pada anak usia dini untuk melatih berbagai keterampilan-keterampilan yang phisik yang begitu bermanfaat di dalam kehidupan anak. Sehingga tujuan tersebut dapat di miliki anak dengan pendidik bekerjasama dengan orang tua dalam meningkatkan motorik halus anak.

\section{B. IDENTIFIKASI MASALAH}

1. Masih banyak anak yang belum meningkat motorik halusnya.

2. Perkembangan motorik halus khususnya kolase pada anak usia 5-6 tahun belum distimulasi secara optimal.

\section{PEMBATASAN MASAlaH}

Agar pembatas masalah mengarah pada tujuan yang akan dicapai maupun di harapkan, maka masalah ini dibatasi pada meningkatkan motorik halus pada anak melalui kolase ampas kelapa di TK MTA MUNGGUR.

\section{PPERUMUSAN MASALAH}

Apakah kolase ampas kelapa dapat meningkatkan motorik halus pada anak usia 5-6 tahun di TK MTA Munggur?

\section{TUJUAN PENELITIAN}

Untuk mengetahui apakah ada pengaruh Kolase Ampas Kelapa terhadap Motorik Halus Anak Usia 5-6 Tahun di TK MTA Munggur Tahun Pelajaran 2016/2017

\section{MANFAAT PENELITI}

1. Manfaat Teoritis

a. Secara teoritis peneliti ini diharapkan dapat menambah pengetahuan dalam bidang pendidikan anak usia dini.

b. Dapat menjadi motivasi bagi peneliti lain yang meneliti masalah yang sama secara mendalam.

2. Manfaat Praktis

a. Bagi Guru

Secara praktis peneliti ini diharapkan dapat menjadi pengetahuan sekaligus informasi tentang cara meningkatkan motorik halus. Sehingga guru bisa meningkatkan motorik halus siswanya.

b. Bagi Siswa

Siswa diharapkan dapat meningkatkan motorik halusnya.

c. Bagi Sekolahan

Untuk sekolahan TK MTA Munggur diharapkan mampu memfasilitasi anak didiknya dalam meningkatkan motorik halus. 
Siti Bari'ah. Meningkatkan Motorik Halus Melalui Kolase Dari Ampas Kelapa Pada Anak Tk Kelas B Usia 5-6 Tahun

\section{METODE PENELITIAN}

Penelitian akan dilakukan di sekolah TK MTA MUNGGUR yang terletak dikecamatan Mojogedang kabupaten Karanganyar. Penelitian ini akan dilaksanakan bulan Mei - Juni 2017 tahun pelajaran 2016/2017. Subjek dalam penelitian anak usia 5-6 tahun disekolah TK MTA MUNGGUR di kelompok B1 tersebut berjumlah 20 anak yang terdiri atas 6 anak laki-laki dan 14 anak perempuan. Objek dalam penelitian motorik halus anak usia 5-6 tahun. Dalam pertimbangan peneliti mengambil subjek penelitian tersebut karena peneliti mengetahui kondisi kegiatan pembelajaran yang dilaksanakan di TK MTA MUNGGUR tersebut.

Model penelitian ini menggunakan penelitian tindakan kelas, karena peneliti ini melakukan sesuai dengan langkah-langkah pada peneliti tindakan yang meliputi penyusunan rencana, melaksanakan tindakan, mengobservasi, melakukan analisis dan refleksi terhadap hasil observasi dari hasil analisis dan refleksi setiap akhir kegiatan dilakukan tindakan perbaikan terhadap siklus yang selanjutnya berdasarkan hasil analisis dan refleksi yang di buat sebelumnya. Menurut Suharsimi Arikunto (2009:117) pada prosedur penelitian ini menggunakan langkah-langkah penelitian tindakan kelas model siklus di karenakan objek penelitian yang diteliti hanya satu sekolahan. Teknik pengumpulan data dengan menggunakan observasi, wawancara dan dokumentasi.

Validitas data adalah triangulasi yaitu teknik pemeriksaan keabsahan data yang memanfaatkan sesuatu yang lain diluar kota untuk keperluan pengecekan atau sebagai perbandingan terhadap data lain" (Lexy J. Moleong, 2002:178). Analisis data bagian terpenting di dalam penelitian ini.Hasil yang diamati dihitung selanjutnya dipresentasekan sesuai dengan rumus yang digunakan Ngalim Purwanto (2006:102)

Keterangan:

NP : Nilai persen yang dicari/ diharapkan

$\mathrm{R} \quad$ : sekor mentah yang diperoleh
SM : skor maksimum

\section{HASIL PENELITIAN DAN PEMBAHASAN}

Untuk mengetahui kemampuan peserta didik maka peneliti melakukan upaya observasi dengan pra siklus. Sedangkan pra siklus adalah suatu kegiatan sebagai pengamatan untuk mendapatkan data sebatas mana kemampuan peserta didik yang dimiliki sebelum dilakukan tindakan pengamat. Maka peneliti mempersiapkan mempersiapkan yaitu: Perencanaan, Pelaksanaan, Observasi dan Refleksi.

Dalam observasi pra siklus peneliti perlu meningkatkan motorik halus dan mengasah kreatifitas peserta didik didalam kegiatan bermain sambil belajar sebelum tindakan, hasil dari pengamatan jika dibuat presentase rekapitulasi motorik halus sesuai dengan data di atas maka dapat dilihat pada tabel dibawah:

Tabel 1. Rekapitulasi Motorik Halus Pada Anak Pra Siklus

\begin{tabular}{|c|l|c|c|}
\hline No & \multicolumn{1}{|c|}{ Kriteria } & $\begin{array}{c}\text { Jumlah } \\
\text { Anak }\end{array}$ & Presentase \\
\hline 1. & $\begin{array}{l}\text { Berkembang } \\
\text { Sangat Baik }\end{array}$ & 2 & 10 \\
\hline 2. & $\begin{array}{l}\text { Berkembang } \\
\text { Sesuai Harapan }\end{array}$ & 4 & 20 \\
\hline 3. & $\begin{array}{l}\text { Mulai } \\
\text { Berkembang }\end{array}$ & 13 & 65 \\
\hline 4. & $\begin{array}{l}\text { Belum } \\
\text { Berkembang }\end{array}$ & 1 & 5 \\
\hline
\end{tabular}

Maka dapat di baca denilaiaanya masih bawah target yang di harapkan sedangkan saat ini mendapatkan persentase sebanyak $10 \%$ dengan jumlah 2 peserta didik. Jumlah peserta didik yang mulai berkembang atau mulai memiliki keinginan membuatnya berjumlah 13 peserta didik dalam persentase sebanyak $65 \%$. Selanjutnya peneliti melakukan tindakan dengan siklus I. Setelah diadakan suatu perbaikan pada tahap siklus I maka dapat diperoleh hasil dari peningkatan peserta didik jika dibuat persentase rekapitulasi motorik halus data diatas sehingga dapat dilihat pada kolom tabel tersebut: 
Siti Bari'ah. Meningkatkan Motorik Halus Melalui Kolase Dari Ampas Kelapa Pada Anak Tk Kelas B Usia 5-6 Tahun

Tabel 2. Rekapitulasi Data Motorik halus Peserta didik Siklus I

\begin{tabular}{|c|l|c|c|}
\hline No & \multicolumn{1}{|c|}{ Kriteria } & $\begin{array}{c}\text { Jumlah } \\
\text { Anak }\end{array}$ & Presentase \\
\hline 1. & $\begin{array}{l}\text { Berkembang } \\
\text { Sangat Baik }\end{array}$ & 3 & 15 \\
\hline 2. & $\begin{array}{l}\text { Berkembang } \\
\text { Sesuai } \\
\text { Harapan }\end{array}$ & 14 & 70 \\
\hline 3. & $\begin{array}{l}\text { Mulai } \\
\text { Berkembang }\end{array}$ & 3 & 15 \\
\hline 4. & $\begin{array}{l}\text { Belum } \\
\text { Berkembang }\end{array}$ & 0 & 0 \\
\hline
\end{tabular}

Berdasarkan tabel diatas 9. dapat dilihat motorik halus peserta didik pada pelaksanaan penelitian siklus I. Sehingga dapat dilihat hasilnya yang mendapatkan kriteria berkembang sangat baik sebanyak 3 peserta didik dengan jumlah persentase $15 \%$. Sedangkan yang memiliki kriteria berkembang sesuai harapan sebanyak 14 peserta didik dengan jumlah persentase 70\%. Dalam kriteria mulai berkembang sebanyak 3 peserta didik dengan jumlah persentase $15 \%$ peserta didik. Sehingga semakin kelihatan peningkatan motorik peserta didik di dalam pesentase tabel tersebut.

Berdasarkan penelitian dan pengamatan langsung yang dilakukan pada tahap siklus yang ke I maka peneliti dan peserta didik akan melakukan analisis terhadap proses bermain sambil belajar dan terhadap motorik halus. Saat melakukkan analisis dengan pendidik sehingga peneliti dan pendidik menemuk suatu keberhasilan dan kegagalan dalam tahap siklus I. Maka disini peneliti melakukan tindakan selanjutnya karena belum berkembang sangat baik selanjutnya melakukan tindakan dengan siklus II dan melakukan evaluasi terhadap peserta didik dan pendidiknya maka selanjutnya. Dikarenakan pola yang rumit disiklus I selanjutnya peneliti menggunakan pola yang sederhana. Peneliti merencanakan sebaik mungkin dari evaluasi siklus sebelumnya. Maka hasil dari siklus II selesai kegiatan peneliti meminta untuk membereskan bahan dan alat pada tempat semula dan melakukan evaluasi dalam kegiatan. Hasilnya seperti dibawah ini:
Jika dibuat persentase rekapitulasi motorik halus data di bawah sehingga dapat dilihat pada kolom tabel tersebut:

Tabel 3. Rekapitulasi Data Motorik Halus Siklus II

\begin{tabular}{|c|l|c|c|}
\hline No & \multicolumn{1}{|c|}{ Kriteria } & $\begin{array}{c}\text { Jumlah } \\
\text { Anak }\end{array}$ & Presentase \\
\hline 1. & $\begin{array}{l}\text { Berkembang } \\
\text { Sangat Baik }\end{array}$ & 17 & 85 \\
\hline 2. & $\begin{array}{l}\text { Berkembang } \\
\text { Sesuai } \\
\text { Harapan }\end{array}$ & 3 & 15 \\
\hline 3. & $\begin{array}{l}\text { Mulai } \\
\text { Berkembang }\end{array}$ & 0 & 0 \\
\hline 4. & $\begin{array}{l}\text { Belum } \\
\text { Berkembang }\end{array}$ & 0 & 0 \\
\hline
\end{tabular}

Menurut tabel 3. dapat dilihat peningkatan motorik halus terhadap peserta

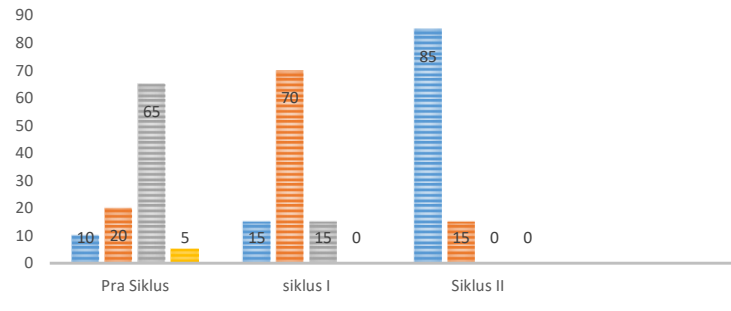

didik pada pelaksanaan pada siklus II yang mempunyai kriteria berkembang sangat baik sebanyak 17 peserta didik dengan memiliki persentase $85 \%$. Sedangkan dengan kriteria berkembang sesuai harapan sebanyak 3 peserta didik dengan memiliki persentase $15 \%$. Melebihi tarjet yang diharapkan. Pada kegiatan refleksi pada tahap siklus II lebih mengarah evaluasi terhadap proses dan hasil suatu pelaksanaan yang dilakukan setiap hari. Secara menyeluruh pelaksanaan pada siklus II berjalan sesuai dengan rencana. Sesuai dengan hasil pengamatan peneliti dan pendidik dapat menyimpulkan bahwa kegiatan kolase dengan ampas kelapa dapat meningkatkan motorik halus peserta didik telah menunjukkan suatu keberhasilan. Suatu keberhasilan dapat ditunjukan dengan tabel dibawah ini: 
Siti Bari'ah. Meningkatkan Motorik Halus Melalui Kolase Dari Ampas Kelapa Pada Anak Tk Kelas B Usia 5-6 Tahun

Tabel 4. Rekapitulasi Data Motorik Halus Peserta didik Pra Siklus, Siklus I, Siklus II

\begin{tabular}{|c|l|l|l|l|c|c|c|}
\hline \multirow{2}{*}{ No } & \multirow{2}{*}{ Kriteria } & \multicolumn{2}{|c|}{ Pra Siklus } & \multicolumn{2}{c|}{ Siklus I } & \multicolumn{2}{c|}{ Siklus II } \\
\cline { 3 - 8 } & & $\begin{array}{l}\text { Frek } \\
\text { uens } \\
\text { i }\end{array}$ & $\begin{array}{l}\text { Pers } \\
\text { enta } \\
\text { se }\end{array}$ & $\begin{array}{l}\text { Fre } \\
\text { kue } \\
\text { nsi }\end{array}$ & $\begin{array}{c}\text { Per } \\
\text { sen } \\
\text { tas } \\
\text { e }\end{array}$ & $\begin{array}{c}\text { Fre } \\
\text { kue } \\
\text { nsi }\end{array}$ & $\begin{array}{c}\text { Per } \\
\text { sen } \\
\text { tas } \\
\text { e }\end{array}$ \\
\hline 1. & BSB & 2 & 10 & 3 & 15 & 17 & 85 \\
\hline 2. & BSH & 4 & 20 & 14 & 70 & 3 & 15 \\
\hline 3. & MB & 13 & 65 & 0 & 0 & 0 & 0 \\
\hline 4. & BB & 1 & 5 & 0 & 0 & 0 & 0 \\
\hline \multicolumn{6}{c}{ Dari tabel 4. } & \multicolumn{3}{c|}{ dapat diketahui } \\
\hline
\end{tabular}
perkembangan peserta didik dalam motorik halus berdasarkan sesuai dengan kriteria berkembang sangat baik sebanyak 2 peserta didik yang memiliki persentase $10 \%$, sedangkan kriteria berkembang sesuai dengan harapan sebanyak 4 peserta didik dengan memiliki persentase 20\%. Dengan kriteria belum berkembang 1 peserta didik dengan sejumlah persentase $5 \%$ Dalam kriteria mulai berkembang mulai berkembang sebanyak 3 peserta didik dengan memiliki persentase $15 \%$. Berdasarkan siklus I dengan kriteria berkembang sangat baik sebanyak 3 dengan memiliki persentase $15 \%$. Sedangkan dengan kriteria berkembang sesuai harapan sebanyak 14 peserta didik dengan jumlah persentase $70 \%$. Sedangkan pada siklus II dengan kriteria berkembang sangat baik sebanyak 17 peserta didik dengan memiliki persentase $85 \%$. Sedangkan dengan kriteria berkembang sesuai dengan harapan sebanyak 3 peserta didik dengan memiliki persentase $15 \%$. Menurut hasil dari data pada tabel rekapitulasi meningkatkan motorik halus pada peserta didik pra siklus, siklus I, dan siklus II sehingga dapat dijelaskan sesuai dengan gambar dibawah ini:

Gambar 1. Grafik Persentase Peningkat Motorik Halus Peserta Didik Pra Siklus, Siklus I dan, Siklus II

Menurut grafik di atas dapat dilihat begitu jelas dengan peningkatan motorik halus peserta didik pra siklus sebanyak $10 \%$, siklus I sebanyak $15 \%$ dan siklus II sebanyak 85\%. Sehingga keberhasilan dapat dilihat dengan peningkatan dari setiap siklus dengan pencapaian indikator keberhasilan terhadap siklus II dengan pencapaian $85 \%$. Dari hasil menunjukkan pada siklus II lebih bagus dibanding dengan siklus I dikarenakan pada persentase peningkatan pada siklus II lebih tinggi dibanding dengan peningkatan persentase pada siklus I. Maka dengan kegiatan kolase ampas kelapa dapat meningkatkan motorik halus peserta didik.

\section{SIMPULAN}

Berdasarkan analisis data dari hasil penelitian tindakan kelas yang sudah dilaksanakan melalui tahap pra siklus, siklus I dan siklus II maka dapat disimpulkan sebagai berikut: Berdasarkan hasil penelitian menunjukkan bahwa melalui kegiatan kolase dari ampas kelapa dapat meningkatkan motorik halus anak, dapat dibuktikan dari kondisi awal mendapatkan persentase sebanyak $10 \%$ dengan 2 peserta didik. Pada siklus I sebanyak $15 \%$ dengan 3 peserta didik. Selanjutnya siklus II pertemuan pertama sudah mengalami peningkatan yang derastis $80 \%$ dengan jumlah 16 peserta didik pada siklus II pertemuan ke-2 sebanyak $85 \%$ dengan jumlah 17 peserta didik. Melalui kegiatan kolase ampas kelapa dapat meningkatkan motorik halus, dapat menempel sesuai dengan pola dengan sabar, dan dapat mengkoordinasi mata dan dapat menggerakkan pergelangan tangan agar lentur bagi anak sebagai dorongan meningkatkan motorik halus.

\section{SARAN}

1. Bagi pendidik dalam hal memberikan kegiatan bermain sambil belajar sebaiknya menggunakan benda-benda di lingkungan sekitar semisal ampas kelapa.

2. Bagi peneliti selanjutnya diharapkan untuk mengkaji lebih banyak sumber maupun refrensi yang terkait dengan sarana prasarana pendidikan maupun efektifitas proses pembelajaran agar hasil dari penelitian lebih baik dan lengkap lagi.

\section{DAFTAR PUSTAKA}

Bambang Sujiono. 2008. Penilaian Perkembangan Belajar Anak Taman Kanak-Kanak. Jakarta: Universitas Terbuka. 
Siti Bari'ah. Meningkatkan Motorik Halus Melalui Kolase Dari Ampas Kelapa Pada Anak Tk Kelas B Usia 5-6 Tahun

Hajar Pamadhi, Evan Sukardi. 2010. Seni Keterampilan Anak. Yogyakarta: Universitas Terbuka.

Lexy J. Moleong. 2002. Metodologi Penelitian Kualitatif. Bandung: PT Remaja Rosdakarya.
Mursid, 2015. Belajar dan Pembelajaran PAUD. Bandung: PT Remaja Rosdakarya Offset.

Suharsimi Arikunto, Suhardjono, Supardi. 2009. Penelitian Tindakan Kelas. Jakarta: PT Bumi Aksara. 